International Research Journal of Management, IT \& Social Sciences
Available online at https://sloap.org/journals/index.php/irjmis/
Vol. 8 No. 2, March 2021, pages: 148-154
ISSN: 2395-7492
https://doi.org/10.21744/irjmis.v8n2.1325

\title{
The Development Strategy of Civil Association Cooperative
}

\author{
Nekky Rahmiyati ${ }^{a}$ \\ Sri Andayani ${ }^{b}$ \\ Endang Indartuti ${ }^{c}$
}

\section{Article history:}

Submitted: 27 December 2020

Revised: 18 January 2020

Accepted: 09 February 2021

\section{Keywords:}

cooperative citizen association; development strategy;

SWOT analysis;

\begin{abstract}
Cooperatives' existence and role in supporting national economic activities are essential and strategic. Strengthening the cooperative economy and small business economy is a priority. Kediri City received the cooperative award from the Ministry of Cooperatives and MSME in 2017. The award was given because it successfully guided and developed Cooperatives. Until now Kediri City has a cooperative citizen association (CA) that has been formed. One hundred fifty cooperatives from a total of 352 CA have been created in the city. Data analysis using SWOT analysis is a strategic planning method used to evaluate strengths, weaknesses, opportunities, and threats in a project or business speculation. These four factors make up the SWOT acronym (strengths, weaknesses, opportunities, and threats). They are used to determine the strategy for developing a CA Cooperative in Kediri. Based on the calculation from the results of the SWOT analysis, the total score of the internal strategic factor analysis (IFAS) obtained a score of 2.54, and this shows that The CA Cooperative has an excellent strength to face the opportunities and threats that occur.
\end{abstract}

International research journal of management, IT and social sciences (C) 2021. This is an open access article under the CC BY-NC-ND license (https://creativecommons.org/licenses/by-nc-nd/4.0/).

\section{Corresponding author:}

Nekky Rahmiyati,

Universitas 17 Agustus 1945 Surabaya, Indonesia.

Email address: nekky@untag-sby.ac.id

\footnotetext{
${ }^{a}$ Universitas 17 Agustus 1945 Surabaya, Indonesia

${ }^{b}$ Universitas 17 Agustus 1945 Surabaya, Indonesia c Universitas 17 Agustus 1945 Surabaya, Indonesia 


\section{Introduction}

Cooperatives' existence and role in supporting national economic activities, especially in overcoming problems of poverty, small business actors, and gaps between sectors, are essential and strategic (Sarwoko, 2009; Abidin, 2008; Amri, 2020; Fitriati, 2015). Therefore strengthening the cooperative economy and small business economy is a priority towards creating strong economic fundamentals. The number of cooperatives in Indonesia is quite large, but this large number is not necessarily followed by adequate quality. Many cooperatives are left with only names and legal entities, but their activities are not running. According to data from the East Java Cooperatives and MSME Office, the total assets of cooperatives in East Java, to date, have reached IDR 34 trillion. The turnover is IDR 47 trillion with a Remaining Business Result (SHU) of IDR 5.3 trillion and has absorbed a workforce of 62,000 people. In Kediri city, through the Office of Cooperatives for Micro Enterprises and Manpower, it has facilitated and formed a Citizens Association (CA) Cooperative. Until now, 150 cooperatives have been formed from a total of 352 Citizens Association (CA), in addition to women's co-ops in the villages. In 2015, the number of cooperative units in Kediri City in 2015 were 473 cooperatives (Winarto, 2020; Muzdalifa et al., 2018; Thaha, 2020; Saprianto, 2020).

The Process of the CA Cooperative Development Strategy through the SWOT Analysis Stages. SWOT analysis is a strategic technique in evaluating strengths, weaknesses, opportunities, and threats that can be applied to activities including business and business, education, projects, or even to yourself (Marcelino-Sádaba et al., 2014). Sebt et al. (2018) said that SWOT analysis is a strategic planning method used to evaluate the strengths, weaknesses, opportunities, and threats in a project or business speculation. These four factors make up the SWOT acronym (strengths, weaknesses, opportunities, and threats). SWOT will be better discussed using tables made in the large paper, so that the relationship from each aspect can be properly analyzed (Reihanian et al., 2012; Caineng et al., 2013; SerokaStolka, 2014).

\section{Materials and Methods}

The strategy of developing community-based community cooperatives in Kendari City in improving the community economy is the main objective of this quantitative study. In understanding how communities improve their cooperatives, we conduct a series of data collection. After the data was collected, we analyzed it with a strategic SWOT analysis system (Jackson et al., 2003; Kajanus et al., 2012; Yuan, 2013). We analyze the strengths, weaknesses, opportunities, and threats in a project or business speculation. Through SWOT analysis, we identified all the potentials of this community-based cooperative. With this SWOT analysis, we have understood that this community-based cooperative has many strengths, including the obedience of citizens to continue to become cooperative partners. Then the average cooperative management is both financial management and service management of members who are cooperative customers. Through the SWOT method, we believe the data generated is valid and reliable under Gürel \& Tat (2017), direction in their SWOT analysis: a theoretical review.

\section{Results and Discussions}

Research Framework

Table 1

Number of internal and external strategic factors

\begin{tabular}{llc}
\hline 1 & Strength & 2,12 \\
2 & Weakness & 0,42 \\
3 & Opportunities & 1,96 \\
4 & Threats & 0,56 \\
5 & Internasional analysis coordinate $(\mathrm{X})$ & 1,7 \\
6 & Internasional analysis coordinate $(\mathrm{Y})$ & 1,4 \\
\hline
\end{tabular}

Rahmiyati, N., Andayani, S. ., \& Indartuti, E. (2021). The development strategy of civil association cooperative. International Research Journal of Management, IT and Social Sciences, 8(2), 148-154. 
Table 2

Area of Matrix and Strategy Priority

\begin{tabular}{llllll}
\hline Quadrant & Position Point & Matrix Lenght & Rank & Strategic Priority & Strategy \\
\hline SO & $(2,12 ; 1,96)$ & 4,16 & 1 & Growth & Agresif Strategy \\
WO & $(0,42 ; 1,96)$ & 0,83 & 3 & Stability & Turnaround strategy \\
WT & $(0,42 ; 0,56)$ & 0,24 & 4 & Coclusion & Defense strategy \\
ST & $(2,12 ; 0,56)$ & 1,18 & 2 & Kombination & Diversification Strategy \\
\hline
\end{tabular}

Source: Designed data

Note :

a) In quadrant I (S-O Strategy), the general strategy that can be carried out by the Citizens Association (CA) Cooperative is to use the strength of the Citizens Association (CA) cooperative to take every advantage of the opportunity;

b) In quadrant II (W-O Strategy), the CA Cooperative can make an advantage on the occasion as a reference for focusing activities by avoiding weaknesses;

c) In quadrant III (S-T Strategy) Make every strength to face every threat by creating diversification to create opportunities.

d) In quadrant IV (W-T Strategy), the cooperative Citizens Association (CA) minimizes all weaknesses to face every threat.

From data processing to determine the area of the matrix and strategic priorities in Table 5.6 above, the results of the largest matrix area in quadrant I with a matrix area of 4.16 should be noted, but it should also be noted that the area of the matrix in quadrant II also has a sufficiently calculated matrix area, namely 0.83 . A description of the position of the broad quadrant matrix ranking in Table 5.6 above, among others:

1) Rank I: In the 1st quadrant with the area of the matrix 4.16;

2) Rank 2: In quadrant IV with a matrix area of 1.18 ;

3) Rank 3: In quadrant II with a matrix area of 0.83 ;

4) Rank 4: In quadrant III with a matrix area of 0.24 .

Using Swot Strategy, based on the ranking above, is as follows :

First Rangking is Agresive strategy

1) An S-O strategy is a strategy to use your strength to take advantage of existing opportunities. Actors want their business to be in a position where internal strength can be used to take advantage of external trends and events. Study of the development strategy of the Citizens Association (CA) Cooperative in Kediri City includes;

2) Regulations and Legislation, as well as Policies on the Empowerment and Development of CA Cooperatives issued by the Kediri City Government, must provide convenience, but remain on priority and remain selective to support the development of CA Cooperatives;

3) Regulations and Legislation, as well as Policies on the Empowerment of CA Cooperatives issued by the Kediri City Government, must be able to guarantee the continuity of the CA Cooperative business in Kediri City;

4) Guidance and development of CA Cooperatives by the City Government of Kediri need to be continuously improved not only in quantity but in quality, especially in developing and strengthening the competitiveness of Citizens Association (CA) Cooperatives that have been carried out including aspects of cooperative management;

5) The guidance that has been carried out is quite good but following the times and times as well as developments and changes in technology, both appropriate technology, and existing information technology, must be updated (updated) every period;

6) Training and assistance in terms of management of the CA Cooperative need to be improved, whether carried out by the relevant agencies themselves or in collaboration with educational institutions, and other related institutions. The use of computer technology for the management of the Citizens Association (CA) Cooperative. Increase productivity by utilizing appropriate or modern technology according to the ability of cooperative Citizens Association (CA);

7) The plan for airport development in Kediri Regency and toll booths in the Kediri City Area is an opportunity for the development of Citizens Association (CA) Cooperatives to collaborate with the Tour and Travel Bureau to develop tour packages, associated with superior products of MSMEs that become members of CA 
Cooperative as tourism support and if the SMSE is a member of the CA Cooperative, the CA will develop rapidly.

The second rank is diversification Strategy

Diversification Strategy using the strengths of a company to avoid or reduce the impact of external threats. The Diversification Strategy is as follows;

1) The regulations on CA Cooperatives issued by city Kediri should provide convenience in the development of CA cooperative. This is to minimize Government Regulations that can hinder the sustainability of cooperative businesses;

2) There is guidance by the City Government in business functions including: management aspects, capital aspects, human resources aspects, financial aspects, marketing aspects, and information technology aspects. This is to face/ anticipate problems that arise in the development of the CA Cooperative, including a lot of competition with the same business;

3) The existence of guidance by the City Government in business functions in the aspect of increasing the capacity of the CA Cooperative has a strong commitment to implementing modern business management, business vision and mission, translated into clear, measurable, and directed organizational strategies, communication of management, members and supervisors is running well, members have the same opportunity to provide ideas for improvements to the ongoing process;

4) There are several CA Cooperatives that have sufficient capital and assets, also, there is guidance by the Kediri City Government in business functions and aspects of business capital. This is to anticipate or minimize the shortage of working capital for MSMEs who are members of the Citizens Association (CA) Cooperative because not many financial institutions are willing to make it easier to get additional business capital for MSMEs that do not have assets as collateral. On the other hand, in cooperatives, it is very easy to get loans with low-interest rates.

\section{The third Rank is Turn Around strategy}

The second strategy is turning around, namely the $\mathrm{W}-\mathrm{O}$ (Weakness- Opportunity) Strategy. This strategy aims to correct internal weaknesses by taking advantage of external opportunities. The strategy for optimizing the empowerment of cooperative should be carried out by this turn around strategy;

1) Co-operatives that apply a conventional business management system feel that they have been left behind. The Cooperative Office holds various types of training to provide additional insight into business management. This includes including training carried out by the Ministry and Provincial Government.

2) Vision and Mission of cooperative, which was previously only used as a jargon without a clear definition and strategic direction, communication between leaders and employees goes in one direction. Members tend to be passive in providing ideas for improving cooperative performance, now it must be changed. With a large number of professional cooperative managers, it is sufficient to run a business. This is also supported by empowerment through relevant agencies on training to provide additional insight into business management. Participate in training carried out by the Ministry and Provincial Government, for example: technology guidance on business management, Organizing comparative studies to increase the insight and technical competence of cooperatives, and hold a Cooperative CA competition in Kediri City.

3) Empowerment of CA cooperatives through promotional and marketing aspects; Cooperating with modern markets to accommodate local products that meet the criteria for sale in modern markets and Strengthening the cooperative movement.

4) With a large number of cooperatives and other financial institutions in Kediri, there is a lot of competition in business. This can be anticipated by optimizing existing opportunities, including: the application of low-interest rates in CA cooperatives is a major opportunity for MSMEs that require capital, it's easy to become a member of a cooperative and the existence of the annual member meeting shows the transparency in cooperative management.

Rahmiyati, N., Andayani, S. ., \& Indartuti, E. (2021). The development strategy of civil association cooperative. International Research Journal of Management, IT and Social Sciences, 8(2), 148-154. 
Fourth Rank Defensive Strategy

The defensive strategy is the W-T (Threats - Weaknesses) Strategy of the CA Cooperative which faces various external threats and internal weaknesses and is really in a dangerous position;

1) In reality, such a CA cooperative may have to struggle to survive, merge, downsize, declare bankruptcy or choose liquidation, which is the last option if it is very difficult to do so or switch business with similar materials or complementary products or substitute products;

2) In the CA Cooperative, which is in this condition, the City Government's efforts to carry out a development strategy for the cooperatives city Kediri are; improving cooperative movement and increase public awareness of the role of cooperatives in community economic development;

3) Improve the human resources of cooperative managers by providing technical guidance;

4) Building economic growth centers, art markets, industrial centers, but at low prices to attract the desire of tourists to visit intensely, develop promotions in various ways according to the conditions of MSMEs as members of the CA Cooperative.

\section{Covid-19 Impact on the Development of CA Cooperatives}

Regional Quarantine is a restriction on the population in an area including the Entrance Area and its contents suspected of being infected with a disease and/ or contamination. Some of the activities that have been eliminated to the point of being limited include dismissing schools, working at home or work from home, limiting religious activities, limiting activities in public places, limiting socio-cultural activities, and limiting transportation modes. If you violate it, you will be penalized. Ranging from mild to severe if you keep repeating; the number of workers who were laid off and economic growth slows down.

One sector that is having difficulty withstanding the impact of Covid-19 is Micro, Small, and Medium Enterprises (MSMEs). Some of the things that happened include: Sales decreased; Raw material difficulty; stunted distribution; Production Difficulty; Capital Difficulties. This condition also has an impact on the development of RCA Cooperatives in Kediri City. From a survey conducted on Respondents, it can be concluded that Covid-19 has had a huge impact on the development of CA Cooperatives. Inline can be conveyed, with the existence of Covid-19, the CA Cooperative Business is very disturbed, including the following:

1) No technology guarantees the continuity of the cooperative's business;

2) There is no financial institution that is willing to provide additional business models;

3) Not all cooperative managers are competent in the field of cooperatives because most of them are housewives;

4) Member difficulties in repaying the loan lack of funds in fulfilling Member loans;

5) Several Members are experiencing difficulties in paying loan installments and voluntary savings due to the impact of the Covid-19 pandemic.

The hopes of members and administrators of the CA Cooperative in facing this condition are:

1) Request to increase guidance and assistance There is support from the Cooperative office both through increasing human resources and equipment needed in cooperative operations

2) So that the Department of Cooperatives and UMTK facilitate regular loan funds for cooperatives with easy terms and a fast liquid process for loans to cooperatives.

3) The Department of Cooperatives and UMTK is expected to help socialize both to the community and equipment at the village and CA levels for the advancement of the CA Cooperative and the supervision of the performance of the Management in the CA Cooperative so that it can progress and develop.

4) The Department of Cooperatives and UMTK should continue to provide guidance, especially on financial management / financial reports;

The Department of Cooperatives and UMTK are expected to provide assistance and assistance in the process of managing legal entities for CA cooperatives. 
4 Conclusion

Based on the presentation of the data and the results of the SWOT analysis and the discussion of the strategies above, in the Study of the Optimization Strategy for Empowerment of CA Cooperatives in Kediri City, it can be recommended as follows;

1) It is best to review the applicable Regulations and Policies on CA Cooperative Development. Each period needs to be evaluated what its shortcomings and weaknesses are, what are the advantages cooperatives that operate in the business sector are always faced with changes.

2) Strengthening Capital Assistance for CA Cooperatives, especially active and inactive cooperatives, a Cooperative Restructuring is required.

3) Formation of new CA Cooperatives should be carried out in 2 patterns, namely (General Pattern and Special Pattern) the general pattern or bottom-up, namely the formation of CA cooperatives from under the meaning of pre-cooperative institutions that already exist in their respective CA. The Special Pattern or Top-down Pattern in which a CA Cooperative is deliberately formed from and by the City Government.

4) The limited human resources owned by the management and members of cooperatives so that there is a need for guidance in the field of training and assistance, especially in the field of cooperatives and information technology skills.

5) There needs to be a rating of CA cooperatives and holding competitions on cooperative CA. There must be 102 active cooperatives CA.

6) Assistance to active cooperatives can be done in collaboration with Higher Education Institutions, with the Business World.

7) An airport development plan in Kediri Regency and toll booths in the Kediri City Area is an opportunity for the development of CA Cooperatives to collaborate with the Tour and Travel Bureau to develop tour packages.

\section{Conflict of interest statement}

The authors declared that they have no competing interests.

\section{Statement of authorship}

The authors have a responsibility for the conception and design of the study. The authors have approved the final article.

\section{Acknowledgments}

The authors would like to thank all colleagues and faculty members for their support from the inception of writing to the completion of this project. Likewise, the university's editing and proofreading assistance as well as the valuable feedback they have provided. While for this research fund, we have the names of the authors' members who have successfully managed all of our needs in a project entitled "The Strategy for Community Cooperative Development in Kendari City in improving the community economy through SWOT analysis."

Rahmiyati, N., Andayani, S. ., \& Indartuti, E. (2021). The development strategy of civil association cooperative. International Research Journal of Management, IT and Social Sciences, 8(2), 148-154. 


\section{References}

Abidin, A. (2008). Pengembangan Usaha Micro Kecil dan Menengah (UMKM) Sebagai Kekuatan Strategis dalam Mempercepat Pembangunan Daerah. AKMEN Jurnal Ilmiah, 5(4).

Amri, A. (2020). Dampak covid-19 terhadap UMKM di Indonesia. BRAND Jurnal Ilmiah Manajemen Pemasaran, 2(1), 123-131.

Caineng, Z., Zhi, Y., Jingwei, C., Rukai, Z., Lianhua, H., Shizhen, T., ... \& Jingli, Y. (2013). Formation mechanism, geological characteristics and development strategy of nonmarine shale oil in China. Petroleum Exploration and Development, 40(1), 15-27. https://doi.org/10.1016/S1876-3804(13)60002-6

Fitriati, R. (2015). Menguak Daya Saing UMKM Industri Kreatif: Sebuah Riset Tindakan Berbasis Soft Systems Methodology. Yayasan Pustaka Obor Indonesia.

Gürel, E., \& Tat, M. (2017). SWOT analysis: a theoretical review. Journal of International Social Research, 10(51).

Jackson, S. E., Joshi, A., \& Erhardt, N. L. (2003). Recent research on team and organizational diversity: SWOT analysis and implications. Journal of management, 29(6), 801-830. https://doi.org/10.1016/S0149-2063(03)000801

Kajanus, M., Leskinen, P., Kurttila, M., \& Kangas, J. (2012). Making use of MCDS methods in SWOT analysisLessons learnt in strategic natural resources management. Forest Policy and Economics, 20, 1-9. https://doi.org/10.1016/j.forpol.2012.03.005

Marcelino-Sádaba, S., Pérez-Ezcurdia, A., Lazcano, A. M. E., \& Villanueva, P. (2014). Project risk management methodology for small firms. International journal of project management, 32(2), 327-340. https://doi.org/10.1016/j.ijproman.2013.05.009

Muzdalifa, I., Rahma, I. A., \& Novalia, B. G. (2018). Peran fintech dalam meningkatkan keuangan inklusif pada UMKM di Indonesia (pendekatan keuangan syariah). Jurnal Masharif al-Syariah: Jurnal Ekonomi dan Perbankan Syariah, 3(1).

Reihanian, A., Mahmood, N. Z. B., Kahrom, E., \& Hin, T. W. (2012). Sustainable tourism development strategy by SWOT analysis: Boujagh National Park, Iran. tourism management Perspectives, 4, $223-228$. https://doi.org/10.1016/j.tmp.2012.08.005

Saprianto, F. (2020). Dilematis UMKM di Era Digital. SCIENTIFIC JOURNAL OF REFLECTION: Economic, Accounting, Management and Business, 3(1), 21-30.

Sarwoko, E. (2009). Analisis Peranan Koperasi Simpan Pinjam/unit Simpan Pinjam dalam Upaya Pengembangan UMKM di Kabupaten Malang. Jurnal Ekonomi Modernisasi, 5(3), 172-188.

Sebt, M. H., Khalilianpoor, A. H., Bagheri, Q., \& Riahi Dehkordi, E. (2018). SWOT Analysis on Marine Transport Companies of Iran: a case Study. AUT Journal of Civil Engineering, 2(2), 153-160.

Seroka-Stolka, O. (2014). The development of green logistics for implementation sustainable development strategy in companies. Procedia-Social and Behavioral Sciences, 151, 302-309. https://doi.org/10.1016/j.sbspro.2014.10.028

Thaha, A. F. (2020). Dampak covid-19 terhadap UMKM di Indonesia. BRAND Jurnal Ilmiah Manajemen Pemasaran, 2(1), 147-153.

Winarto, W. W. A. (2020). Peran Fintech dalam Usaha Mikro Kecil dan Menengah (UMKM). Jesya (Jurnal Ekonomi dan Ekonomi Syariah), 3(1), 61-73.

Yuan, H. (2013). A SWOT analysis of successful construction waste management. Journal of cleaner production, 39, 1-8. https://doi.org/10.1016/j.jclepro.2012.08.016 